IZA DP No. 8038

Housing Adequacy Gap for Minorities and Immigrants in the U.S.:

Evidence from the 2009 American Housing Survey

Kusum Mundra

Amarendra Sharma

March 2014 


\title{
Housing Adequacy Gap for Minorities and Immigrants in the U.S.: Evidence from the 2009 American Housing Survey
}

\author{
Kusum Mundra \\ Rutgers University \\ and IZA \\ Amarendra Sharma \\ Elmira College \\ Discussion Paper No. 8038 \\ March 2014 \\ IZA \\ P.O. Box 7240 \\ 53072 Bonn \\ Germany \\ Phone: +49-228-3894-0 \\ Fax: +49-228-3894-180 \\ E-mail: iza@iza.org
}

\begin{abstract}
Any opinions expressed here are those of the author(s) and not those of IZA. Research published in this series may include views on policy, but the institute itself takes no institutional policy positions. The IZA research network is committed to the IZA Guiding Principles of Research Integrity.

The Institute for the Study of Labor (IZA) in Bonn is a local and virtual international research center and a place of communication between science, politics and business. IZA is an independent nonprofit organization supported by Deutsche Post Foundation. The center is associated with the University of Bonn and offers a stimulating research environment through its international network, workshops and conferences, data service, project support, research visits and doctoral program. IZA engages in (i) original and internationally competitive research in all fields of labor economics, (ii) development of policy concepts, and (iii) dissemination of research results and concepts to the interested public.
\end{abstract}

IZA Discussion Papers often represent preliminary work and are circulated to encourage discussion. Citation of such a paper should account for its provisional character. A revised version may be available directly from the author. 
IZA Discussion Paper No. 8038

March 2014

\section{ABSTRACT}

\section{Housing Adequacy Gap for Minorities and Immigrants in the U.S.: Evidence from the 2009 American Housing Survey}

Home adequacy for different groups in the U.S. has not been adequately studied. Using the data from the national level American Housing Survey for the year 2009and logit model, this paper finds that there is a significant adequacy difference for Blacks and Hispanics when compared to whites in the U.S. However, that is not the case for immigrants relative to the natives. We also find that then naturalization improves housing adequacy among immigrant homeowners, whereas, the female headed households have a significantly higher home adequacy than that of the male headed households. Similar to the homeownership findings, this paper highlights that the public policies should aim to narrow the home adequacy gap between whites and minorities and encourage naturalization to improve adequacy among immigrant homeowners.

JEL Classification: R2, J15

Keywords: housing adequacy gap structural adequacy, U.S. residential real estate, immigrants, minorities, American Housing Survey, naturalized

Corresponding author:

Kusum Mundra

Department of Economics

Hill Hall 804

Rutgers University

Newark, NJ 07102

USA

E-mail: kmundra@andromeda.rutgers.edu 


\section{Introduction}

Provision of adequate housing is an important issue and has been declared such by many international instruments including the Universal Declaration of Human Rights, which states (article 25(1)): "Everyone has the right to a standard of living adequate for the health and wellbeing of himself and his family,...." On the other hand, the International Convention on the Protection of the Rights of all Migrant Workers and Members of their Families (article 43(1)(d) states that "Migrant worker shall enjoy equality of treatment with nationals of the state of employment in relation to...[a]ccess to housing, including social housing schemes, and protection against exploitation in respect to rents."

These international declarations notwithstanding, we still observe significant proportion of people living in inadequate housing in many countries including the richest in the world. Of course, the quality of housing in absolute terms varies by country, and a country like United States, which is perceived to have high absolute standards regarding adequacy of homes when compared with other countries, still has disparities regarding the relative adequacy when compared internally. It is therefore not surprising to learn that approximately 5.33 million single and multifamily homes in the United States have been characterized as moderately or severely inadequate by the HUD (Barry et al., 2011). According to the United States Department of Agriculture, the homes in the rural areas, whether owner or rental structure, have higher rates of physical inadequacies than the homes in the urban areas, but tend to be less crowded. This housing issue assumes an added dimension when we consider the demographic makeup of the U.S., which has seen a steady growth in the population of immigrants in particular and minorities in general. In spite of this shift of the demographic forces towards the minorities, who traditionally have lower homeownership rates than the whites, the homeownership rates in the 
U.S. saw a jump of 4.6 percentage points during the recent housing boom (Nations' Housing Outlook 2010). This observed increase can primarily be attributed to the household income growth and low interest rates. A report from the Pew Hispanic Center showed that from 1994 onwards home ownerships have also increased dramatically for the minorities and the immigrants (Kochar et al., 2009).

There is a vast literature examining the homeownership outcome for minorities and immigrants, but the housing literature has not adequately examined home adequacy gap for both minorities and immigrants. In this paper, our main focus is to estimate the homeownership adequacy differences for minorities and immigrant homeowners using the national level American Housing Survey for the year 2009.

Earlier literature on this issue has found that housing adequacy does vary by race and nativity in the U.S. Kutty (1999) while examining the determinants of structural adequacy of dwellings using the metropolitan 1991 AHS data concludes that "significant disparity in housing quality exists across metropolitan areas and population groups by race, household type, tenure, and central city or suburban location".

Grisby and Bourassa (2004) use data from the 2001 American Housing Survey and find that the new immigrant households are more likely to be crowded, though blacks and Hispanic households, regardless of the nativity status, are more likely to live in poor quality housing.

In this paper we are revisiting the housing adequacy disparity issue for minorities and immigrants in the U.S. We call it an adequacy gap because the past research and anecdotal evidence has shown that in spite of the significant strides in homeownerships, significant proportion of minorities and immigrants still live in less adequate housing than whites and natives. Minorities and immigrants might live in less adequate housing due to financial and 
geographical reasons but a priori this disparity might also exist because of cultural factors or the group effect. A black individual might live in a neighborhood with a majority of black population, or immigrants settle in immigrant gateway centers, where the housing is known to be of lower adequacy.

This paper makes two important contributions. First, we use the data from the AHS (2009) at the national level to examine the housing adequacy gap for minorities and immigrants. Second, for the immigrant homeowners we examine the role of naturalization in improving adequacy of homes. Academic literature on housing has explored in detail the realization of American dream of homeownership for immigrants and minorities. Using the 2009 American Housing sample this study aims to answer some of the pertinent questions that have not been adequately addressed by the literature on the housing adequacy gap across minorities and immigrant groups.

\section{Background Literature on Housing Adequacy in the U.S.}

A plethora of research has been done on the adequacy of housing in the United States. Some of the issues related to the quality of housing that have been discussed in the literature are how to measure housing quality, what determines housing quality, and how home prices relate to housing quality. Researchers agree that the measure of housing quality must be multidimensional and ought to include a measure of structural adequacy, a measure of neighborhood quality that emphasizes safety, access to work and other amenities, a measure of crowding in the house, and certainly affordability.

For example, after analyzing AHS data, Goedert and Goodman (1977) and Wieand and Clemmer (1977) find that no single measure of housing inadequacy serves as a good proxy for housing quality as they are weakly correlated with other measures of structural deficiency or the 
household characteristics.

In another study, Goodman (1978) considers three indicators of housing quality, namely, financial burden, crowding, and unit and neighborhood quality scores based on a hedonic index. The determinants of these quality indicators in his study are primarily demand side variables such as income, family size, race, and education. Kutty (1999) does a similar study using the AHS data, but she includes both demand and supply side determinants in her analysis. She, in addition to the above mentioned variables, includes age of the building, type of the structure, tenure, elderly status of the residents, and vehicle ownership as the determinants of housing quality.

Goedert and Goodman (1977) find that dwellings in the rural areas are more likely to suffer from structural deficiencies than the urban areas, and also the rental homes tend to be more structurally deficient than the owner occupied dwellings.

Spain (1990) in her multivariate study uses crowding as an indicator of housing quality and finds that a dwelling is more crowded if the household is married, have children, and resides in the central city. On the other hand, income is inversely related to crowding.

Weicher and Thibodeau (1988) find that the likelihood of residing in low quality housing increases with one's racial minority status and being unmarried. Whereas, being married, low vacancy, and new construction are associated with lower odds of living in low quality housing. They do not find any evidence to suggest that the construction of subsidized housing for poor results in a reduction of the occurrence of low quality housing.

There are several studies that discuss the appropriate indicators of housing quality. Goedert and Thibodeau (1977) do not use any predetermined measure of housing quality in their study, rather they rely on those indicators of housing deficiency that have significant inverse relationship with 
the household income. This criterion allowed them to choose indicators such as lacking electric outlets in one or more rooms, absence of plumbing facility, presence of mice and rats, and leaky roofs.

Kain and Quigley (1970) use factor analysis to aggregate variables to represent housing quality into five factors. These factors are: basic residential quality, dwelling unit quality, proximate unit quality, non-residential use, and average structure quality. A study by HUD (1978) defines inadequate housing. Accordingly, if a dwelling lacks one or more of the structural features such as sewage, kitchen, plumbing, heating, public hall, toilet access, and electrical fittings, then it's considered inadequate. This definition has been used by several studies including Weicher and Thibodeau (1988), Weicher, Yap, and Jones (1982), Newman and Schnare (1988), Newman and Struyk (1983), Bianchi, Farley, and Spain (1982), and Kutty (1999).

Cook \& Bruin (1994) examine the determinants of housing quality for White, Hispanic, and African-American single parent women. Their study uses three indicators of housing quality; viz., Affordability, Crowding, and Satisfaction. They find that white single women fared better than their Hispanic or African-American counterparts in terms of living in a better quality home. The Hispanic single mother household was more crowded and incurred greater housing related costs than the other groups. The African-American single mothers were more likely to live in substandard housing and more dissatisfied relative to the other groups.

Choi (1999) using the 1991 wave of the American Housing Survey data examines the determinants that predict the quality of housing headed by people older than 65 years in age. The finding suggests that older minority women are more likely to live in a deficient house than the older white females.

Boehm (1995) compares the costs and the perceived quality of owned manufactured homes with 
the traditional rented and owner occupied homes by using data from the American Housing Surveys of 1985-1989. He finds that the manufactured homes compare well with the traditional ones because of its low cost and perceived better structural quality. He also looks at specific structural attributes in influencing the household's perceived ordinal rankings of the structural quality of homes and finds that the same attributes play a role across all tenure types.

Markham and Gilderbloom (1998) examine the determinants of housing inadequacy for the elderly and find that the region where the person lives and the race are the most important predictors. They also find that the tenure and the gender of the elderly person also predict the housing inadequacy. Other factors that they identify to be associated with housing inadequacy among elderly are: being black, living in the south, living alone, and being a renter.

In this paper we use the recent national level 2009 AHS to examine not only the housing adequacy gap for blacks and Hispanics but also for the immigrants. Housing adequacy is measured by the AHS measure of structural inadequacy. This paper further contributes to the literature by examining the housing adequacy for female household heads and for the naturalized vs. the non-naturalized immigrants.

\section{Data}

This paper uses data from the AHS 2009. The AHS is a biennial national housing survey conducted by the Bureau of the Census for the Department of Housing and Urban Development (HUD). ${ }^{1}$ The AHS is the only national sample which collects data on various quality indicators and detail information on the physical unit and so has been the principal data source for housing quality for the U.S. The AHS gives rich information on the households' demographic characteristics, race, immigrant characteristics, homeowner's mortgage information and 
neighborhood characteristics. Our focus is on Hispanics and blacks, and immigrants are identified by household heads born outside of the U.S. to non-American parents. ${ }^{2}$

It is well known that housing adequacy decreases in urban areas relative to the suburban areas. In the national sample we control for various levels of geography. We include region, detail SMSA control, and whether the unit is in the urban area or not. In addition to the above broad geography controls we also include whether the unit is in the central city or not. However, even within the cities there is a tremendous variation in the housing adequacy because of the characteristics and conveniences of the location. For instance, some buildings are inadequate and are still owned or rented in cities because of their proximity to public transportation. Thus, in addition to the above geography controls, we also include a narrower geographic control of whether the unit has a satisfactory neighborhood public transportation or not.

We use the multidimensional adequacy index ZADEQ recorded in the AHS for our quality measure. ${ }^{1}$ This index has been previously used in many studies (see for example, Kutty, 1999; Lu, 1999; Hadden \& Lager, 1990). We reclassify the three levels of adequacy in the index to a binary measure (Binadequacy) that takes value 1 when $\mathrm{ZADEQ}=1$ (housing quality is adequate) and zero when the ZADEQ $=2$ or 3 (structural adequacy is moderately inadequate or severely inadequate). ${ }^{2}$ The details of the housing adequacy measure are provided in the Appendix. From the summary data in Table 1 we find that $67 \%$ of the household heads are homeowners and $41 \%$ are the first time homeowners. A very high proportion at $95 \%$ has adequate housing, and $26 \%$

\footnotetext{
${ }^{1}$ The variable ZADEQ to measure home adequacy, however, is not without some limitations. As Eggers \& Moumen (2013) point out that "this variable is oriented toward the lowest level standard of housing adequacy. It uses a limited three point scale, contrasting adequate housing with two levels of inadequacies. The ZADEQ scale does not offer any levels of contrast in housing that is deemed adequate. In spite of this caveat ZADEQ has been widely used in the literature, since it gives a potential lower level of threshold on adequacy.

${ }^{2}$ Another reclassification could have been severely inadequate versus not. Though, a more relevant and interesting question for the U.S. is whether minorities and immigrants live in adequate housing compared to whites and natives. In this paper we focus on this binary adequacy discussion.
} 
say that they have moderate neighborhood satisfaction. Thirty-seven percent of the homes are more than twenty five years old and $65 \%$ of the units are single family homes. Seventy one percent of the households report that they enjoy high neighborhood satisfaction, whereas, $6 \%$ of the units have abandoned buildings in the neighborhood. The average length of tenure is around 11 years and the average room density is around 3 persons per room.

Fifty five percent of the households are married and $43 \%$ are female heads. Seventy percent of the households are non-Hispanic whites and $11 \%$ are blacks and $12 \%$ Hispanics. Fourteen percent of the households are immigrants and the average time they have spent in the U.S. is around twenty two years. Forty six percent of the immigrant households are naturalized. Eighty percent own cars and twenty five percent have assets. Thirty one percent are college graduates and the average monthly household income is around $\$ 5,826$. Twenty three percent of the units are located in the Northeast, twenty five percent in the Midwest, nineteen percent in the West, and thirty one percent in the South.

When we compare the means across various groups (presented in Table 3), we find that a significantly higher proportion of immigrants compared to natives have adequate housing in the U.S. Similarly a significant proportion of whites live in adequate housing compared to blacks and Hispanics. To further examine the disparity gap in a multivariate framework we use a logit model discussed in the next section.

\section{Empirical Model}

The empirical models are based on logit models of housing adequacy given as follows:

$$
\text { Binadequacy } i=f\left(X_{i}, Z_{i}\right)
$$


where the vector $\mathrm{X}$ includes controls for the demand and supply side of the adequacy index and $\mathrm{Z}$ contains the relevant minority and immigrant status dummy variables. Binadequacy $=$ 1 if $y>0$, where $y$ is an unobservable latent variable specified as follows:

$$
y=\beta_{0}+X \beta_{1}+Z \beta_{2}+\varepsilon
$$

and $\varepsilon$ follows a logistic distribution $\mathrm{G}($.$) . So the$

$$
\text { Probability }\left(\text { Binadequacy }=1 \mid X_{i}, Z_{i}\right)=\mathrm{G}\left(\beta_{0}+X \beta_{1}+Z \beta_{2}\right)
$$

where $\mathrm{Z}$ includes the dummy variables Black, Hispanici, and Immigrant $i$

The vector $\mathrm{X}$ includes both demand and supply side determinants of housing adequacy. On the demand side determinants of housing adequacy we include variables such as the education of household head and household income. Generally, the higher the level of education and household income the greater is the chance of a household living in an adequate home. Following Kutty (1999) we proxy permanent income by including asset and car ownership by the household. We also include whether the household owns or rents, presence of children below 18 years of age, as well as the number of children. We control for other demographic factors such as the marital status and gender of the household head. We also control for how satisfied the household head is with the neighborhood they live in. If the individuals are satisfied with the neighborhood then their demand for more adequate housing will be higher. However, there is also a possibility that if the household head, particularly the renters, are very satisfied with the neighborhood then they might be willing to substitute the lower adequacy of their home with the better neighborhood quality. 
On the supply side determinants of housing adequacy in vector $X$ in model 1 we include variables such as the age of the building and whether the unit is a single family or multifamily. Multifamily and older units are more likely to be inadequate than the single and newer units. We also include a few geographical controls such as whether the unit is in the urban area, central city, and controls for various regions. Housing in central city is often overcrowded than the suburban areas and therefore the homes would tend to have lower adequacy index than the suburban areas. Within the cities we further use narrower location controls such as whether the unit has a satisfactory public transportation nearby or not.

To examine the housing adequacy gap for Hispanics and Blacks we include a dummy variable capturing the ethnicity of the household in model 1. We also include a dummy variable to capture the immigration status of the household head. In another specification we estimate model (2) for the immigrants only and include a naturalization dummy and the number of years the immigrants have lived in the U.S. Similar to the homeownership argument, the longer the immigrants have lived in the U.S. the more assimilated they become and tend to have an upward income trajectory (Borjas 1994; Chiswick 1978; Chiswick and Miller 2000). Thus, one would expect that with greater assimilation coupled with better information about the housing market and higher earnings, the immigrants can afford to live in homes with a high degree of adequacy. However, it is also possible that with the increased immigration during the 1970s and 1980s more immigrants settled in the central city compared to the newer arrivals. This might lower the adequacy and quality of housing for immigrants as a function of the number of years lived in the U.S. In order to further examine the adequacy gap for immigrants, we estimate the following model for immigrant sample and control for their years in the U.S. and whether they are naturalized or not: 


$$
\text { Probability }\left(\text { Binadequacy }=I \mid X_{i}, Z_{1}\right)=\mathrm{G}\left(\beta_{0}+X \beta_{1}+Z \beta_{2}\right)
$$

Where $Z=$ Black $_{i}$, Hispanic, , Years in the $U S_{i}$, Naturalized $i$

\section{Results}

Next, we discuss the results from our analysis of the various model specifications mentioned above.

Table 4 presents the estimation results from the logit model given by equation (2). ${ }^{3}$ We find that the Blacks and Hispanics have lower likelihood of living in an adequate home than the whites. The odds ratio suggests that the Blacks have $31 \%$ and Hispanics 19\% lower likelihood of living in an adequate home compared to the whites and the results are statistically significant at $1 \%$ for both Blacks and Hispanics. ${ }^{4}$ The other variables have expected signs. We find that household heads with college education and higher incomes have greater likelihood of living in an adequate house. Individuals who own a car have a 1.22 times higher likelihood of living in an adequate housing compared to non-car owners. Home owners have a 1.44 time higher likelihood of living in an adequate housing than the renters. However, we find that the length of ownership is inversely related to the likelihood of a household reporting living in an adequate housing.

The other variables also exhibit expected signs. Married household heads have a higher likelihood of living in adequate housing than widowed and single household heads. Individuals living in moderate and low neighborhood satisfaction areas have a lower likelihood of living in adequate housing than the households with high neighborhood satisfaction areas. It is not surprising that individuals living in a single family detached homes show a higher housing

\footnotetext{
${ }^{3}$ In this paper we focus on a binary discussion of adequacy but our main results also hold in ordered logit.

${ }^{4}$ If we redefine Zadeq as adequacy versus severe inadequacy, the Hispanic dummy is insignificant but Blacks continue to have significant severe inadequacy compared to the whites. We thank an anonymous referee for this suggestion.
} 
adequacy than multifamily units. Also, mobile homes and abandoned units have lower home adequacy than other units.

We find that the female headed households show 1.12 times higher likelihood of living in an adequate housing than the male headed households, and the result is statistically significant at the five percent level. This finding on home adequacy is contrary to that of homeownership. Previous literature on gender homeownership gap has shown that women have significantly lower homeownership rates than men (Sedo and Kassoudji 2004). The households with female heads show a higher adequacy than their male counterparts and are in contrast to the gender gap in homeownership. This shows that among women once they are homeowners they are more inclined to live in adequate housing and spend more resources in home maintenance. This result is interesting as it suggests narrowing the gender gap in homeownership might lead to an increase in the adequate housing stock.

The results with the immigrant dummy in model 2 are given in Table 4 columns $4 \& 5$. We find that the immigrants and natives do not have any statistically significant quality gap. This finding on home adequacy for immigrants is different from that of homeownership. It is well known that immigrants have substantial homeownership gap compared to the natives (Borjas, 2002; Myers and Liu, 2005). After controlling for income, wealth, ownership, and unit characteristics we find that immigrants on average have similar adequacy as natives. Our results show that race is an important indicator of adequacy gap in the U.S. than the immigration status. One possible explanation for this result could be that the minorities such as blacks, whether rich or poor, tend to live in neighborhoods where the supply of homes lack in adequacy, which could be a result of 
homeowners spending less on the maintenance and upkeep of their homes or lack of supply of adequate homes. $^{5}$

In equation (4) we estimate a model just for the immigrant only sample, displayed in table 5 . We find that the naturalized immigrants have 1.43 times higher likelihood of living in adequate housing than the non-naturalized immigrants and this result is statistically significant at the $10 \%$ level. This result holds even when we account for the immigrant's assimilation in the U.S. Number of years in the U.S. lowers the likelihood of adequate housing but is insignificant. Naturalization signals permanence for immigrants in their new destination countries and often signals less mobility and a higher likelihood of homeownership. All the above factors tend to improve the adequacy of housing and thus naturalization lowers the home adequacy gap for the immigrants. From Table 5, we also find that the race dummy is insignificant among immigrants. After we account for income and wealth and other factors there is no significant adequacy gap among various racial groups.

\section{Conclusions}

Given the significance of homeownership in individual wealth creation and in the household's integration into the society, there has been a big push towards encouraging homeownership in the U.S. In addition, given the homeownership gap for minorities and immigrants, the U.S. government has taken many policy measures to encourage homeownership for the low income households. There is a vast literature on minorities and immigrant homeownership in the U.S.

\footnotetext{
${ }^{5}$ Given 2009 was a recession year there might be a possibility that we are overestimating the effect of race on adequacy. One could argue that a recession is a macro phenomenon and the effect of recession is felt across all groups. Though, we do allow the heterogeneity of the effect of recession across race in our model by controlling for whether the household was receiving unemployment benefits or enrolled in a welfare program and our results across race do not change.
} 
but the literature is weak on the home adequacy differences for various groups in the U.S. Our paper aims to fill this gap in the literature.

Using the national sample of 2009 AHS and the adequacy index, the main findings of this paper are that there is a significant home adequacy gap for blacks and Hispanics compared to the whites, even after controlling for income, demographic, and geographical differences. This points toward a possible cultural effect of minorities living in inadequate housing and spending less on home maintenance and upkeep. There are possible supply side factors such as the neighborhoods where minorities reside have relatively more inadequate housing structures than the other neighborhoods. However, we do not find any home adequacy gaps for the immigrants compared to the natives. In this paper we also find a couple of additional interesting results. (1) Female headed households are more likely to live in adequate housing than the male headed households, (2) Naturalized immigrants tend to live in better quality homes than the nonnaturalized immigrants. 


\section{References}

Barry, L. S., et. al. Worst Case Housing Needs 2009: A Report to Congress. February, 2011. Retrieved from :http://www.huduser.org/portal/publications/affhsg/wc_HsgNeeds09.html

Bianchi, S. M.; R. Farley, and D. Spain. Racial Inequalities in Housing: An Examination of Recent Trends. Demography, 1982, 19:1, 37-51.

Boehm T. P. A Comparison of the Determinants of Structural Quality between Manufactured Housing and Conventional Tenure Choices: Evidence from the American Housing Survey. Journal of Housing Economics, 1995, 4:4, 373-391.

Borjas G. Long-Run Convergence of Ethnic Skill Differentials: The Children and Grandchildren of the Great Migration. Industrial and Labor Relations Review. 1994.47(4), 553-573.

-- 2002. Homeownership in the immigrant population, Journal of Urban Economics, 52: 448476.

Chiswick, Barry. 1978 "The Effect of Americanization on the Earnings of Foreign-born Men," The Journal of Political Economy, 86(5), pp. 897-921.

Chiswick, B. R. and P. W. Miller. Immigrant Earnings: Language Skills, Linguistic Concentrations and the Business Cycle. Journal of Population Economics. 2002.

Choi N.G. Differences in the Quality of Housing Units Occupied by Elderly Men versus Elderly Women. Journal of Housing for the Elderly, 1999,13:1-2, 93-113. DOI:10.1300/J081v13n01_08.

Cook C. C. and M. J. Bruin. Determinants of housing quality: A comparison of white, AfricanAmerican, and Hispanic single-parent women. Journal of Family and Economic Issues, 1994, 15: 4, 329-347. DOI: 10.1007/BF02353809.

Eggers, F J. and F. Moumen. American Housing Survey: A Measure of (Poor) Housing Quality. 2013, Econometric Inc., Betheseda, MD.

Goedert, J. E. and J. L. Goodman. Indicators of the Quality of US Housing.1977, 249: 2, Urban Institute.

Goodman, A. C. Hedonic Prices, Price Indices and Housing Markets. Journal of Urban Economic, 1978, 5:4, 471-484.

Hadden, L. and M. Lager. Codebook for the American Housing Survey: Cambridge MA: Abt Associates. 1990. 
International Convention on the Protection of Rights of Migrant Workers and Members of Their Families, GA Res 45/158, Annex, 45 UN GAOR Suppl. (No. 49A) at 262, UN Doc. A/45/49 (1990).

Kain, J. F. and J. M. Quigley. Measuring the Value of Housing Quality. Journal of American Statistical Association.1970, 65, 532-48.

Kutty, N.K. Determinants of Structural Adequacy of Dwellings. Journal of Housing Research. 10(1), 1999, 27-43.

Lu M. Determinants of Residential Satisfaction: Ordered Logit vs. Regression Models. Growth and Change. 1995, 30, 264-287.

Markham J. P. and J. I. Gilderbloom. Housing Quality among the Elderly: A Decade of Changes. The International Journal of Aging and Human Development, 1998, 46:1, 71-90.

Myers, D. and C. Y. Liu. The emerging dominance of immigrants in the US housing market 1970-2000"; Urban Policy and Research, 2005, 23:3, 347-65; 2005.

Newman, S. J., and R. J. Struyk. Housing and Poverty. The Review of Economics and Statistics. 1983, 243-253.

Newman, S.J. and A.B. Schnare. Subsidizing Shelter: The Relationship between Welfare and Housing Assistance. 1988, 1, The Urban Institute.

Sedo, S. A. and S. A. Kossoudji. 2004. Room of One's Own: Gender, Race and Home Ownership as Wealth Accumulation in the United States. IZA Discussion Paper \# 1397.

Spain, D. Housing Quality and Affordability among Female Householders. In Housing Demography, 1990, ed. D. Myers, Madison, WI: University of Wisconsin Press.

Wieand, K. and R.Clemmer. The Annual Housing Survey and Models of Housing Services Output. Paper read at the Meeting of the American Real Estate and Urban Economics Association. May 1977, Washington, DC.

Weicher, J. C., et al. Metropolitan Housing Needs for the 1980s. 1982, Urban Institute Press.

Weicher, J. C. and T. G. Thibodeau. Filtering and Housing Markets: An Empirical Analysis. Journal of Urban Economics, 1988, 23:1, 21-40.

Universal Declaration of Human Rights, adopted and proclaimed by the United Nations General Assembly by resolution 217A (III) on 10 December 1948.

\section{End Notes}

1. http://www.census.gov/hhes/www/housing/ahs/ahs.html). 
2. Asians are also a significant category for understanding immigrant and minority homeownership in the U.S., but we had to exclude this group from the present analysis due to small sample size.

3. We can only do this analysis for homeowners since for this group we know the year they obtained the mortgages. This analysis also serves as robustness check for our results for the overall sample where the homeownership might be endogenous to the adequacy measure.

\section{Appendix}

ZADEQ is a three level index of the multidimensional standards of adequacy. The three levels are

(1) adequate, (2) moderately inadequate, and (3) severely inadequate. In this paper we convert ZADQ to a binary measure and define a unit as adequate if ZADEQ is adequate at the first level and inadequate if ZADEQ is at the second or third level.

The AHS codes ZADEQ as severely inadequate if the unit meets just one of the following conditions:

- Unit has less than 2 bathrooms and the unit has at least one of the following:

Unit does not have hot and cold running water

Unit does not have a bathtub or shower

Unit does not have a flush toilet

Unit shares plumbing facilities

- Unit was cold for 24 hours or more and there have been

More than two breakdowns of the heating equipment that lasted longer than 6 hours

- Electricity is not used

- Unit has exposed wiring and not every room has 
Working electrical plugs and the fuses have blown more than twice

Additionally, ZADEQ is coded moderately or severely inadequate using the following criteria:

Determine how many of the following conditions the unit meets:

- Unit has had outside water leaks in the last 12 months

- Unit has had inside water leaks in the last 12 months

- Unit has holes in the floor

- Unit has open cracks wider than a dime

- Unit has an area of peeling paint larger than 8x11

- Rats have been seen recently in the unit

If the unit meets 5 or 6 of the conditions, then ZADEQ is coded 3 meaning the unit is severely inadequate

If the unit meets 3 or 4 of the conditions and has not been identified as being severely

inadequate, then ZADEQ is coded 2 meaning the unit is moderately inadequate

If the unit has not been identified as being severely inadequate and meets one of the following conditions:

There have more than two breakdowns of the toilet that lasted longer than 6 hours

The main heating equipment is unvented room heaters burning kerosene, gas, or oil

The unit is lacking complete kitchen facilities

Then ZADEQ is coded 2 meaning the unit is moderately inadequate 
Table 1 Variable Description

\begin{tabular}{|c|c|}
\hline Variable & Description \\
\hline \multicolumn{2}{|l|}{ Education } \\
\hline lthhsch | & Less than high school \\
\hline somecol & High School but less than College \\
\hline college & College Graduate \\
\hline \multicolumn{2}{|c|}{ Income and Wealth } \\
\hline hhldinc & Annual Household Income \\
\hline carown & Car or Vehicle owner \\
\hline debt & Household Debt \\
\hline asset & Household Assets \\
\hline \multicolumn{2}{|c|}{ Family and Related } \\
\hline prehild & Presence of young children ( $<18$ years) old $)$ \\
\hline children & Number of young children $(<18$ years old $)$ \\
\hline femalehead & Female Head \\
\hline $\operatorname{mar}$ & Married \\
\hline widowed & Widowed \\
\hline nevmar & Never Married \\
\hline \multicolumn{2}{|l|}{ Race } \\
\hline whitenonhisp & Non-Hispanic White Household \\
\hline blacknonhisp & Non-Hispanic Black Household \\
\hline hispanic & Hispanic Household \\
\hline othernonhisp & Other Non-Hispanic Household \\
\hline \multicolumn{2}{|c|}{ Neighborhood Quality } \\
\hline neighsatis $\sim \mathrm{h}$ & High Neighborhood Satisfaction \\
\hline neighsatis $\sim$ d & Moderate Neighborhood Satisfaction \\
\hline neighsatis $\sim \mathrm{W}$ & Low Neighborhood Satisfaction \\
\hline aban & Abandoned Buildings in the Neighborhood \\
\hline \multicolumn{2}{|c|}{ Age of Building } \\
\hline HOold & Building less than or equal to one year old \\
\hline H5old & Building is one to five years old \\
\hline H10old & Building is five to ten years old \\
\hline H25old & Building is 25 or more years old \\
\hline \multicolumn{2}{|c|}{ Unit Type and Related } \\
\hline sfat & Unit type is single family, attached \\
\hline sfdet & Unit type is single family, detached \\
\hline $\operatorname{mf} 20$ & Unit type is multi family, with less than or equal to 20 units \\
\hline $\mathrm{mf} 21$ & Unit type is multi family, with greater than 20 units \\
\hline $\mathrm{mh}$ & Unit is mobile home \\
\hline roomden & Room density (rooms per person) \\
\hline ltenure & Length of tenure in years \\
\hline \multicolumn{2}{|c|}{ Immigration status } \\
\hline immigrant & Immigrant Household \\
\hline naturalized & Immigrants who have US Citizenship \\
\hline timeus & Time spent in the US \\
\hline \multicolumn{2}{|l|}{ Location } \\
\hline newtrn & Neighborhood public transportation satisfactor \\
\hline centralcity & Central City \\
\hline urban & Urban \\
\hline Northeast & Northeast Region \\
\hline Midwest & Midwest Region \\
\hline West & West region \\
\hline South & South Region \\
\hline \multicolumn{2}{|l|}{ Ownership } \\
\hline own & Homeownership \\
\hline firstown & First homeownership \\
\hline yearfirsth $\sim t$ & Year first home is bought \\
\hline \multicolumn{2}{|l|}{ Adequacy } \\
\hline zadeq & House Adequacy Index \\
\hline Binadequacy & $1=$ Adequate quality, $0=$ inadequate quality \\
\hline
\end{tabular}


Table 2: Descriptive Statistics

\begin{tabular}{|c|c|c|c|c|c|}
\hline Variable & Mean & $\begin{array}{l}\text { Standard } \\
\text { deviation }\end{array}$ & Observation & Minimum & Maximum \\
\hline lthhsch | & .13 & 0.33 & 50871 & 0 & 1 \\
\hline somecol & 0.55 & 0.49 & 50871 & 0 & 1 \\
\hline college & 0.31 & 0.46 & 50871 & 0 & 1 \\
\hline Hhldinc* & 5826.49 & 5852.09 & 50871 & -2248 & 71070 \\
\hline carown & 0.80 & 0.39 & 50871 & 0 & 1 \\
\hline debt & -4.25 & 252.15 & 50871 & -26976 & 0 \\
\hline asset & 0.25 & 0.44 & 50871 & 0 & 1 \\
\hline prchild & 0.34 & 0.47 & 50871 & 0 & 1 \\
\hline children & 0.65 & 1.07 & 50871 & 0 & 9 \\
\hline femalehead & 0.45 & 0.49 & 50871 & 0 & 1 \\
\hline mar & 0.55 & 0.49 & 50871 & 0 & 1 \\
\hline widowed & 0.26 & 0.44 & 50871 & 0 & 1 \\
\hline nevmar & 0.18 & 0.38 & 50871 & 0 & 1 \\
\hline whitenonhisp & 0.70 & 0.45 & 50871 & 0 & 1 \\
\hline blacknonhisp & 0.11 & 0.31 & 50871 & 0 & 1 \\
\hline hispanic & 0.12 & 0.32 & 50871 & 0 & 1 \\
\hline othernonhisp & 0.05 & 0.22 & 50871 & 0 & 1 \\
\hline neighsatis $\sim \mathrm{h}$ & 0.71 & 0.45 & 49055 & 0 & 1 \\
\hline neighsatis $\sim \mathrm{d}$ & 0.26 & 0.44 & 49055 & 0 & 1 \\
\hline neighsatis $\sim$ w & 0.02 & 0.14 & 49055 & 0 & 1 \\
\hline aban & 0.06 & 0.24 & 49474 & 0 & 1 \\
\hline H0old & 0.01 & 0.1 & 50871 & 0 & 1 \\
\hline H5old & 0.05 & 0.23 & 50871 & 0 & 1 \\
\hline H10old & 0.06 & 0.24 & 50871 & 0 & 1 \\
\hline H25old & 0.37 & 0.48 & 50871 & 0 & 1 \\
\hline sfat & 0.06 & 0.24 & 50871 & 0 & 1 \\
\hline sfdet & 0.65 & 0.47 & 50871 & 0 & 1 \\
\hline $\mathrm{mf} 20$ & 0.16 & 0.37 & 50861 & 0 & 1 \\
\hline $\mathrm{mf} 21$ & 0.06 & 0.25 & 50871 & 0 & 1 \\
\hline $\mathrm{mh}$ & 0.04 & 0.2 & 50871 & 0 & 1 \\
\hline roomden & 2.82 & 1.56 & 50871 & 0.22 & 15 \\
\hline ltenure & 11.3 & 12.56 & 50871 & 0 & 90 \\
\hline immigrant & 0.14 & 0.34 & 50871 & 0 & 1 \\
\hline naturalized & 0.46 & 0.50 & 38804 & 0 & 1 \\
\hline timeus & 22.21 & 15.18 & 7217 & 0 & 93 \\
\hline centralcity & 0.28 & 0.45 & 50871 & 0 & 1 \\
\hline urban & 0.74 & 0.43 & 50871 & 0 & 1 \\
\hline own & 0.67 & 0.46 & 50871 & 0 & 1 \\
\hline firstown & 0.41 & .49 & 34113 & 0 & 1 \\
\hline yearfirsth $\sim t$ & & 14.74 & 14045 & 1928 & 2009 \\
\hline Northeast & 0.23 & 0.42 & 50871 & 0 & 1 \\
\hline Midwest & 0.25 & 0.43 & 50871 & 0 & 1 \\
\hline West & 0.19 & 0.39 & 50871 & 0 & 1 \\
\hline South & 0.31 & 0.46 & 50871 & 0 & 1 \\
\hline zadeq & 1.06 & 0.30 & 50871 & 1 & 3 \\
\hline
\end{tabular}




\begin{tabular}{llllll}
\hline Binadequacy & .95 & 0.21 & 50871 & 0 & 1 \\
Newtrn & .57 & .49 & 49575 & 0 & 1 \\
citizen & .92 & .25 & 50871 & 0 & 1
\end{tabular}

* Monthly household income in the AHS includes debt. So some households have negative income.

Table 3: Adequacy of Homeownership - Binadequacy

\begin{tabular}{llll}
\hline Variable & Observations & Mean & t-statistic \\
\hline Natives & 43654 & 0.952 & \\
Immigrants & 7217 & 0.937 & $5.1693^{* * *}$ \\
& & & \\
Whites & 35917 & 0.961 & \\
Hispanics & 6239 & 0.926 & $10.027 * * *$ \\
& & & \\
Whites & 35917 & 0.961 & \\
Black Non-Hispanics & 5872 & .910 & $13.0860^{* * *}$ \\
\hline
\end{tabular}

$* * *$ denotes significant at $1 \%, * *$ denotes significant at $5 \%, *$ denotes

significant at $10 \%$ 
Table 4: Logit Regression Results for Home Adequacy: Full Sample

\begin{tabular}{|c|c|c|c|c|c|c|c|c|c|}
\hline \multirow[b]{2}{*}{ Variables } & \multirow[b]{2}{*}{ Coefficient } & \multirow[b]{2}{*}{$\begin{array}{l}\text { Odds } \\
\text { Ratio }\end{array}$} & \multicolumn{2}{|c|}{ With Immigrants } & \multirow[b]{2}{*}{ Variables } & \multirow[b]{2}{*}{ Coefficient } & \multirow[b]{2}{*}{$\begin{array}{l}\text { Odds } \\
\text { Ratio }\end{array}$} & \multirow{2}{*}{$\begin{array}{l}\text { With } \\
\text { Immigrants } \\
\text { coefficients }\end{array}$} & \multirow[b]{2}{*}{$\begin{array}{l}\text { Odds } \\
\text { Ratio }\end{array}$} \\
\hline & & & Coefficient & $\begin{array}{l}\text { Odds } \\
\text { Ratio }\end{array}$ & & & & & \\
\hline blacknonhisp & $\begin{array}{l}-.37 * * * \\
(.0662)\end{array}$ & $\begin{array}{l}.6902 * * * * \\
(.0457)\end{array}$ & $\begin{array}{l}-.3710 * * * \\
(.0662)\end{array}$ & $\begin{array}{l}.6899 * * * * \\
(.0457)\end{array}$ & H0old & $\begin{array}{l}.6520 * \\
(.3428)\end{array}$ & $\begin{array}{l}1.9194^{*} \\
(.6580)\end{array}$ & $\begin{array}{l}.6554 * \\
(.3428)\end{array}$ & $\begin{array}{l}1.9259^{*} \\
(.6603)\end{array}$ \\
\hline hispanic & $\begin{array}{l}-.2029 * * * * \\
(.0692)\end{array}$ & $\begin{array}{l}.8162 * * * * \\
(.0565)\end{array}$ & $\begin{array}{l}-.2202 * * * \\
(.0740)\end{array}$ & $\begin{array}{l}.8023 * * * \\
(.0593)\end{array}$ & H5old & $\begin{array}{l}1.0794 * * * * \\
(.1687)\end{array}$ & $\begin{array}{l}2.9431 * * * \\
(.4966)\end{array}$ & $\begin{array}{l}1.0791 * * * \\
(.1687)\end{array}$ & $\begin{array}{l}2.9422 * * * \\
(.4964)\end{array}$ \\
\hline othernonhisp & $\begin{array}{l}-.0696 \\
(.0968)\end{array}$ & $.9326(.0902)$ & $\begin{array}{l}-.0872 \\
(.1008)\end{array}$ & $\begin{array}{l}.9164 \\
(.0924)\end{array}$ & H10old & $\begin{array}{l}.8933 * * * \\
(.1402)\end{array}$ & $\begin{array}{l}2.4432 * * * \\
(.3426)\end{array}$ & $\begin{array}{l}.8931 * * * \\
(.1402)\end{array}$ & $\begin{array}{l}2.4426 * * * \\
(.3425)\end{array}$ \\
\hline immigrant & & & $\begin{array}{l}.0449 \\
(.0697)\end{array}$ & $\begin{array}{l}1.0460 \\
(.0729)\end{array}$ & sfat & $\begin{array}{l}.2742 * * \\
(.1181)\end{array}$ & $1.3155 * *(.1553)$ & $\begin{array}{l}.2733^{* *} \\
(.1181)\end{array}$ & $\begin{array}{l}1.3143 * * \\
(.1552)\end{array}$ \\
\hline somecol & $\begin{array}{l}.1910 * * * \\
(.0588)\end{array}$ & $\begin{array}{l}1.210 * * * \\
(.0711)\end{array}$ & $\begin{array}{l}.1947 * * * \\
(.059)\end{array}$ & $\begin{array}{l}1.2150^{* * * *} \\
(.0716)\end{array}$ & $\mathrm{mf} 20$ & $\begin{array}{l}-.4987 * * * \\
(.0749)\end{array}$ & $\begin{array}{l}.6072 * * * \\
(.0455)\end{array}$ & $\begin{array}{l}-.5006^{* * * *} \\
(.0750)\end{array}$ & $\begin{array}{l}.6061 * * * \\
(.0454)\end{array}$ \\
\hline college & $\begin{array}{l}.2037 * * * \\
(.0758)\end{array}$ & $\begin{array}{l}1.2259 * * * \\
(.0930)\end{array}$ & $\begin{array}{l}.2060 * * * \\
(.0758)\end{array}$ & $\begin{array}{l}1.2287 * * * \\
(.0932)\end{array}$ & $\mathrm{mf} 21$ & $\begin{array}{l}-.4501 * * * \\
(.0941)\end{array}$ & $\begin{array}{l}.6375 * * * \\
(.0600)\end{array}$ & $\begin{array}{l}-.4506^{* * * *} \\
(.0942)\end{array}$ & $\begin{array}{l}.6372 * * * \\
(.0600)\end{array}$ \\
\hline hhldinc & $\begin{array}{c}00005^{* * * *} \\
(8.61 \mathrm{e}-06)\end{array}$ & $\begin{array}{c}1.000 * * * \\
(8.61 \mathrm{e}-06)\end{array}$ & $\begin{array}{l}.00005^{* * * *} \\
(8.62 \mathrm{e}-06)\end{array}$ & $\begin{array}{l}1.0000 * * * \\
(8.62 \mathrm{e}-06))\end{array}$ & $\mathrm{mh}$ & $\begin{array}{l}-.4521 * * * \\
(.0983)\end{array}$ & $\begin{array}{l}.6362 * * * * \\
(.0625)\end{array}$ & $\begin{array}{l}-.4526 * * * \\
(.0983)\end{array}$ & $\begin{array}{l}.6359 * * * \\
(.0625)\end{array}$ \\
\hline carown & $\begin{array}{l}1965 * * * \\
(.0522)\end{array}$ & $\begin{array}{l}1.2172 * * * \\
(.0636)\end{array}$ & $\begin{array}{l}.1968 * * * \\
(.0522)\end{array}$ & $\begin{array}{l}1.2175^{* * * *} \\
(.0636)\end{array}$ & roomden & $\begin{array}{l}.1438 * * * \\
(.0236)\end{array}$ & $\begin{array}{l}1.1547 * * * * \\
(.0273)\end{array}$ & $\begin{array}{l}.1444 * * * \\
(.0237)\end{array}$ & $\begin{array}{l}1.1553 * * * \\
(.0274)\end{array}$ \\
\hline prchild & $\begin{array}{l}.0214 \\
(.0860)\end{array}$ & $\begin{array}{l}1.0216 \\
(.0879)\end{array}$ & $\begin{array}{l}.0216 \\
(.0860)\end{array}$ & $\begin{array}{l}1.0218 \\
(.0879)\end{array}$ & ltenure & $\begin{array}{l}-.0041 * \\
(.0022)\end{array}$ & $\begin{array}{l}.9958^{*} \\
(.0022)\end{array}$ & $\begin{array}{l}-.0041 * * * \\
(.0022)\end{array}$ & $\begin{array}{l}.9958^{* * * *} \\
(.0022)\end{array}$ \\
\hline children & $\begin{array}{l}.0447 \\
(.0367)\end{array}$ & $\begin{array}{l}1.0457 \\
(.0383)\end{array}$ & $\begin{array}{l}.0444 \\
(.0367)\end{array}$ & $\begin{array}{l}1.0454 \\
(.0383)\end{array}$ & centralcity & $\begin{array}{l}-.3089 * * * \\
(.0588)\end{array}$ & $\begin{array}{l}.7342 * * * \\
(.0431)\end{array}$ & $\begin{array}{l}-.3092 * * * \\
(.0588)\end{array}$ & $\begin{array}{l}.7341 * * * \\
(.0431)\end{array}$ \\
\hline femalehead & $\begin{array}{l}1170 * * \\
(.0469)\end{array}$ & $\begin{array}{l}1.1242 * * \\
(.0527)\end{array}$ & $\begin{array}{l}.1185^{* *} \\
(.0469)\end{array}$ & $\begin{array}{l}1.1258 * * \\
(.0528)\end{array}$ & urban & $\begin{array}{l}.0910 \\
(.0681)\end{array}$ & $\begin{array}{l}1.0953 * * * \\
(.0746)\end{array}$ & $\begin{array}{l}.0897 * * * \\
(.0681)\end{array}$ & $\begin{array}{l}1.0939 * * * \\
(.0745)\end{array}$ \\
\hline widowed & $\begin{array}{l}-.2624 * * * \\
(.0631)\end{array}$ & $\begin{array}{l}.7691 * * * \\
(.0485)\end{array}$ & $\begin{array}{l}-.2593 * * * \\
(.0632)\end{array}$ & $\begin{array}{l}.7715 * * * \\
(.0487)\end{array}$ & own & $\begin{array}{l}.3631 * * * \\
(.0721)\end{array}$ & $\begin{array}{l}1.4378 * * * * \\
(.1037)\end{array}$ & $\begin{array}{l}.3629 * * * \\
(.0722)\end{array}$ & $\begin{array}{l}1.4374 * * * \\
(.1038)\end{array}$ \\
\hline nevmar & $\begin{array}{l}-.3218 * * * \\
(.0645)\end{array}$ & $\begin{array}{l}.7247 * * * \\
(.0467)\end{array}$ & $\begin{array}{l}-.3171 * * * * \\
(.0649)\end{array}$ & $\begin{array}{l}.7282 * * * \\
(.0472)\end{array}$ & intercept & $\begin{array}{l}2.2502 * * * \\
(.6349)\end{array}$ & & $\begin{array}{l}2.2409 * * * \\
(.6350)\end{array}$ & \\
\hline neighsatis $\sim$ d & $\begin{array}{l}-.2123 * * * \\
. .0482)\end{array}$ & $\begin{array}{l}.8086^{* * *} \\
(.0390)\end{array}$ & $\begin{array}{l}-.2117 * * * \\
(.0482)\end{array}$ & $\begin{array}{l}.8091 * * * \\
(.0390)\end{array}$ & $\mathrm{N}$ & 47492 & & 47492 & \\
\hline neighsatis $\sim \mathrm{W}$ & $\begin{array}{l}-.6811^{* * * *} \\
(.1014)\end{array}$ & $\begin{array}{l}.5060 * * * \\
(.0513)\end{array}$ & $\begin{array}{l}-.6800 * * * \\
(.1014)\end{array}$ & $\begin{array}{l}.5065 * * * \\
(.0514)\end{array}$ & Wald chi $^{2}$ & 2128.42 & & 2132.94 & \\
\hline $\begin{array}{l}\text { aban } \\
\text { newtrn }\end{array}$ & $\begin{array}{l}-.6568 * * * \\
(.0681) \\
.1322 * * \\
(.0570)\end{array}$ & $\begin{array}{l}.5184 * * * \\
(.0353) \\
1.1414 * * \\
(.0651)\end{array}$ & $\begin{array}{l}-.6546 * * * \\
(.0683) \\
.1321 * * \\
(.0570)\end{array}$ & $\begin{array}{l}.5196 * * * \\
(.0354) \\
1.1412 * * \\
(.0651)\end{array}$ & $\begin{array}{l}\text { Pseudo } \mathrm{R}^{2} \\
\text { Metro } \\
\text { control }\end{array}$ & $\begin{array}{l}0.1031 \\
\text { Yes }\end{array}$ & Yes & $\begin{array}{l}0.1031 \\
\text { Yes }\end{array}$ & Yes \\
\hline
\end{tabular}

The figures inside the parentheses are robust standard errors.

$* * *$ denotes significant at $1 \%, * *$ denotes significant at $5 \%, *$ denotes significant at $10 \%$. 


\begin{tabular}{|c|c|c|c|c|c|}
\hline Variables & Cefficient & $\begin{array}{l}\text { Odds } \\
\text { Ratio }\end{array}$ & Variables & Coefficient & $\begin{array}{l}\text { Odds } \\
\text { Ratio }\end{array}$ \\
\hline blacknonhisp & $\begin{array}{l}.1035 \\
(.2466)\end{array}$ & $\begin{array}{l}1.1091 \\
(.2736)\end{array}$ & H10old & $\begin{array}{l}1.0789^{* * * *} \\
(.3893)\end{array}$ & $\begin{array}{l}2.9415 * * * \\
(1.1452)\end{array}$ \\
\hline hispanic & $\begin{array}{l}-.1451 \\
(.1715)\end{array}$ & $\begin{array}{l}.8648 \\
(.1483)\end{array}$ & sfat & $\begin{array}{l}.2554 \\
(.3091)\end{array}$ & $\begin{array}{l}1.2910 \\
(.3991)\end{array}$ \\
\hline othernonhisp & $\begin{array}{l}.0572 \\
(.1822)\end{array}$ & $\begin{array}{l}1.0589 \\
(.1929)\end{array}$ & $\mathrm{mf} 20$ & $\begin{array}{l}-.6606^{* * * *} \\
(.1961)\end{array}$ & $\begin{array}{l}.5165 * * * \\
(.1013)\end{array}$ \\
\hline somecol & $\begin{array}{l}.0920 \\
(.1280)\end{array}$ & $1.0964(.1403)$ & $\mathrm{mf} 21$ & $\begin{array}{l}-.5656^{* *} \\
(.2335)\end{array}$ & $\begin{array}{l}.5679 * * \\
(.1326)\end{array}$ \\
\hline college & $\begin{array}{l}.1321 \\
(.1820)\end{array}$ & $\begin{array}{l}1.1412 \\
(.2077)\end{array}$ & $\mathrm{mh}$ & $\begin{array}{l}-.6568 * * \\
(.2954)\end{array}$ & $\begin{array}{l}.5184 * * \\
(.1531)\end{array}$ \\
\hline hhldinc & $\begin{array}{l}.00004 * * \\
(.00002)\end{array}$ & $\begin{array}{l}1.0004 * * \\
(.00002)\end{array}$ & roomden & $\begin{array}{l}.1881 * * \\
(.0761)\end{array}$ & $\begin{array}{l}1.2069 * * \\
(.0919)\end{array}$ \\
\hline carown & $\begin{array}{l}.2299 * \\
(.1271)\end{array}$ & $\begin{array}{l}1.2584 * \\
(.1599)\end{array}$ & ltenure & $\begin{array}{l}.0006 \\
(.0083)\end{array}$ & $\begin{array}{l}1.0006 \\
(.0086)\end{array}$ \\
\hline prchild & $\begin{array}{l}-.0369 \\
(.1921)\end{array}$ & $\begin{array}{l}.9636 \\
(.1851)\end{array}$ & centralcity & $\begin{array}{l}-.4934 * * * \\
(.1402)\end{array}$ & $\begin{array}{l}.6105 * * * \\
(.0856)\end{array}$ \\
\hline children & $\begin{array}{l}.1355^{*} \\
(.0750)\end{array}$ & $1.1451 *(.0859)$ & urban & $\begin{array}{l}-.2721 \\
(.2568)\end{array}$ & $\begin{array}{l}.7617 \\
(.1956)\end{array}$ \\
\hline femalehead & $\begin{array}{l}.2034 * \\
(.1145)\end{array}$ & $\begin{array}{l}1.2255^{*} \\
(.1403)\end{array}$ & own & $\begin{array}{l}.2338 * * * \\
(.1715)\end{array}$ & $\begin{array}{l}1.2634 \\
(.2166)\end{array}$ \\
\hline widowed & $\begin{array}{l}-.0431 \\
(.1555)\end{array}$ & $\begin{array}{l}.9577 \\
(.1489)\end{array}$ & naturalized & $\begin{array}{l}.3640 * * * \\
(.1383)\end{array}$ & $\begin{array}{l}1.4391 * * * \\
(.1991)\end{array}$ \\
\hline nevmar & $\begin{array}{l}-.0903 \\
(.1430)\end{array}$ & $\begin{array}{l}.9135 \\
(.1306)\end{array}$ & timeus & $\begin{array}{l}-.0026 \\
(.0048)\end{array}$ & $\begin{array}{l}.9973 \\
(.0048)\end{array}$ \\
\hline neighsatis $\sim d$ & $\begin{array}{l}-.1547 \\
(.1190)\end{array}$ & $\begin{array}{l}.8566 \\
(.1019)\end{array}$ & newtrn & $\begin{array}{l}.1132 \\
(.1545)\end{array}$ & $\begin{array}{l}1.1198 \\
(.1730)\end{array}$ \\
\hline neighsatis $\sim$ w & $\begin{array}{l}-.4317^{*} \\
(.2612)\end{array}$ & $\begin{array}{l}.6493 * \\
(.1696)\end{array}$ & intercept & $\begin{array}{l}11.2501 * * * \\
(1.3150)\end{array}$ & \\
\hline aban & $\begin{array}{l}-.6577 * * * \\
(.2016)\end{array}$ & $\begin{array}{l}.5179 * * * \\
(.1044)\end{array}$ & $\mathrm{N}$ & 6130 & \\
\hline H0old & $\begin{array}{l}.1783 \\
(1.0038)\end{array}$ & $\begin{array}{l}1.1952 \\
(1.1999)\end{array}$ & Pseudo $\mathrm{R}^{2}$ & 0.1355 & \\
\hline H5old & $\begin{array}{l}1.4520 * * * \\
(.5095)\end{array}$ & $\begin{array}{l}4.2717 * * * \\
(2.1764)\end{array}$ & $\begin{array}{l}\text { Metro } \\
\text { Control }\end{array}$ & Yes & Yes \\
\hline
\end{tabular}

The figures inside the parentheses are robust standard errors.

$* * *$ denotes significant at $1 \%, * *$ denotes significant at $5 \%$,

$*$ denotes significant at $10 \%$. 